\title{
Relationship of Food Hygiene with Patient Satisfaction in Royal Prima Hospital
}

\author{
Pretty Grace Zalukhu ${ }^{1}$, Zulfendri ${ }^{2}$, Albiner Siagian ${ }^{2}$ \\ ${ }^{1}$ Master Student in Faculty of Public Health, Universitas Sumatera Utara, Medan, Indonesia \\ ${ }^{2}$ Lecturer in Faculty of Public Health, Universitas Sumatera Utara, Medan, Indonesia \\ Email: viennye@gmail.com
}

\begin{abstract}
:
The aim of the study is want to find out Relationship of Food Hygiene with Patient Satisfaction. This type of research is analytic survey research with cross sectional study approach that is by measuring or observing at the same time (once in a while) between the dependent and independent variables. The dependent variable in this study is patient satisfaction, while the independent variable is the quality of food delivery services. The result shows that food hygiene is related to satisfaction of inpatients. If the food hygiene is good, the patient is probably 2.8 times more satisfied than those who claim to be bad.
\end{abstract}

Keywords:

relationships; food hygiene; patient satisfaction

\section{Introduction}

Hospital food standards in Nutrition Installation at Royal Prima Hospital in Medan follow from the standard in the Hospital Feeding Regulations (PPMRS) of 2013 which contains the amount and type of food provided to patients based on the class of care, nutritional value and division of meal time in a day. The preparation of food at the Royal Prima Hospital in Medan was prepared by considering the factors of nutritional needs, eating habits and food budget available and determined by the Hospital Director who became the guideline in the administration of food. The Nutrition Installation of the Royal Prima Hospital in Medan also states that they do not have specific standards relating to the taste of food and the serving of food given to patients. Nutrition Installation at Royal Prima Hospital also has never conducted an evaluation related to the taste of food and the serving of food given to patients.

Based on the results of a preliminary survey conducted on 10 general inpatient patients related to food delivery problems at Royal Prima Hospital, showed that some patients rated the quality of food services at the hospital to be poor, which found many patients who complained about the timeliness of food distribution, the problem of food taste, besides that the patient also felt the menu being served seemed monotonous or not a variety of food so that many patients felt uneasy with the food being served. The results of this survey are also supported by the results of direct observations in the inpatient rooms of the Royal Prima Medan Hospital, that there are indeed many leftovers in the patient's food container.

\section{Review of Literature}

\subsection{Organization of Hospital Food}

Hospital food management can be interpreted as a series of activities ranging from menu planning to food distribution to patients. This includes recording and evaluating in order to achieve optimal health status through proper dieting. Hospital food delivery is carried out with the aim of providing good quality food in quantities that are in accordance with the needs and adequate and adequate services for patients in need. 
As for the target of the organization of food in the hospital is the patient. In accordance with the conditions of the Hospital can also be held for visitors (outpatients or patients' families). The provision of food that meets balanced nutrition and is consumed is one way to accelerate healing and shorten the day of hospitalization (Ministry of Health Republic of Indonesia, 2012).

\subsection{Concept of Hospital Nutrition Services.}

Nutrition services in hospitals are services provided and adjusted to the patient's condition based on clinical condition, nutritional status, and metabolic status of the body. The nutritional state of the patient is very influential in the process of healing the disease, on the contrary the process of the course of the disease can affect the nutritional state of the patient. It often happens that the patient's condition is getting worse because of the inadequate need for nutrients for the repair of organs. The function of the organ that is disturbed will get worse with the presence of disease and malnutrition.

In addition, the problem of over nutrition and obesity is closely related to degenerative diseases. Such as diabetes mellitus, hypnotic coronary heart disease. and cancer, requiring nutritional therapy to help cure it. Nutrition therapy or diet therapy is part of the treatment of diseases or clinical conditions that must be considered so that its administration does not exceed the ability of organs to carry out the function of metabolism. Nutritional therapy must always be adapted to changes in organ function. The patient's diet must be evaluated and improved according to changes in clinical conditions and laboratory results both inpatients and outpatients. Efforts to improve the nutritional status and public health both inside and outside the hospital must be straightforward and the responsibility of health workers, especially nutrition workers.

\subsection{Hospital Food Service Quality}

Food service at the hospital can be determined by several indicators including variations in menu, how to serve, and timeliness of serving food, the right time to eat, cleanliness of food served, attitudes and behavior of officers serving food (Suryawati, 2014). The patient's acceptance of the food served can be seen from the rest of the food, if the food served properly can be consumed by the patient, it means that the hospital's nutrition service is achieved (Ministry of Health Republic of Indonesia, 2012)

\subsection{Definition of Patient Satisfaction}

The word satisfaction comes from the Latin "static" (meaning pretty good, adequate) and "facto" (doing or making). In simple satisfaction can be interpreted as "efforts to fulfill something" or "make something adequate". However, from the perspective of consumer behavior, the term customer satisfaction then becomes something complex (Supranto, 2014). Next. Kotler (2013) suggests that satisfaction is a feeling of pleasure or disappointment someone who appears after comparing between his perception or impression of the performance or results of a product and its expectations.

Westbrook \& Reilly argues that satisfaction is an emotional response to customer experiences relating to certain products or services purchased, retail outlets, or even behavioral patterns (such as shopping behavior and buyer behavior), and the market as a whole (Tjiptono, 2015). Howard \& Sheth in Supranto (2014), revealed that customer satisfaction is the cognitive situation of the buyer regarding the comparability or incompatibility between the results obtained compared to the sacrifices made. Mowen in Tjiptono (2015) also formulates customer satisfaction as an overall attitude towards goods and services after their acquisition and use. In other words, customer satisfaction is a full evaluative evaluation resulting from a specific purchase selection. 


\section{Research Method}

This type of research is analytic survey research with cross sectional study approach that is by measuring or observing at the same time (once in a while) between the dependent and independent variables. The dependent variable in this study is patient satisfaction, while the independent variable is the quality of food delivery services.

This research was conducted at Royal Prima Hospital Medan. Timing of this study began in November 2019 until completion. The sample in this study is part of the population. Samples were taken using accidental sampling technique. In this study, samples were taken accidentally, namely patients who were being treated at RSU Royal Prima Medan at the time the researchers conducted the study. To determine the sample size the sample size formula is used in a limited population (Sugiyono, 2014):

$$
\mathrm{n}=\frac{\mathrm{N}(\mathrm{Z}((1-\mathrm{a} / 2\} 2(\mathrm{P})(1-\mathrm{P})}{(\mathrm{N}-1) \mathrm{d} 2+\mathrm{Z}(1-\mathrm{a} / 2) 2(\mathrm{P})(1-\mathrm{P})}
$$

Information:

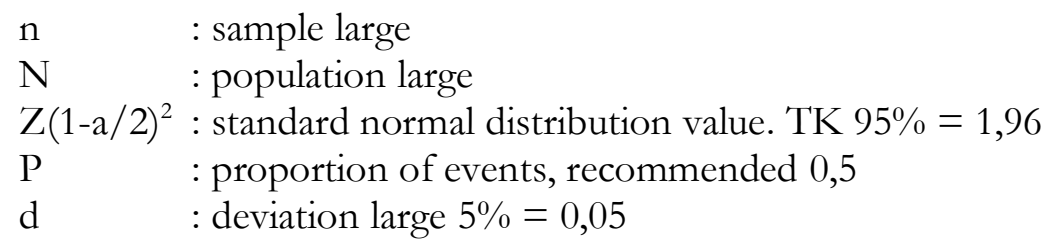

Is known:

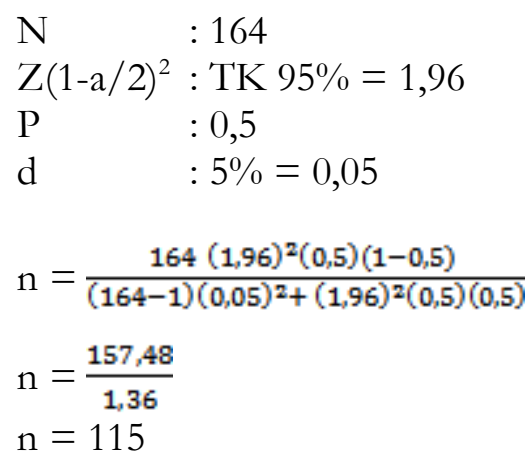

The r-table value for the 30 respondents tested was 0.361 . Questionnaire provisions are said to be valid in this study that is if the value of the $\mathrm{r}$-count variable $\geq 0.361$ is declared valid. If the $\mathrm{r}$-count value of the variable $<0.361$ is declared invalid. The validity test results of the research instruments showed that all items were declared valid because all items had r-count values $>0.361$ (Data is attached in the Appendix of the validity and reliability test).

The higher the reliability of an instrument, the higher the reliability of the instrument. The reliability coefficient is an important indicator of the quality of the instrument. Interpretations for comparing group levels, coefficients ranging from 0.60 and 0.70 are generally adequate, although coefficients of 0.80 or greater are desirable (Polit \& Beck, 2012).

Based on the results of testing the reliability of research data that all research variables are declared reliable because the Cronbach Alpha value of each variable studied is greater than 0.600 (Cronbach Alpha $>0.600)$. Variable accuracy of food serving $(0,699)$, food performance variable 
$(0,678)$, food taste variable $(0,608)$, food hygiene variable $(0,799)$, attitudes supporting health workers $(0,610)$, tangible variable $(0,680)$, reliability variable $(0,685)$, responsiveness variable (0.843), assurance variable (0.657), and empathy variable (0.663) (Data attached in the Appendix of the validity and reliability test).

Validity test is a measure that shows the ability or closeness of an instrument to state what should be measured (Sastroasmoro \& Ismael, 2011). Validity test aims to determine the extent of a measure or value that indicates the level of reliability or validity of a measuring instrument by measuring the correlation between variables or items with a total score of variables using the Pearson product moment $(r)$ correlation formula, provided that the $r$-count value $>r$-table, then declared valid and vice versa (Sugiyono, 2015).

The r-table value for the 30 respondents tested was 0.361. Questionnaire provisions are said to be valid in this study that is if the value of the $r$-count variable $\geq 0.361$ is declared valid. If the $r$-count value of the variable $<0.361$ is declared invalid. The validity test results of the research instruments showed that all items were declared valid because all items had r-count values $>0.361$ (Data is attached in the Appendix of the validity and reliability test).

Reliability is the accuracy of a measurement, to determine the consistency of an instrument in measuring the target attributes, if the measurements made repeatedly in different times will give the same results (Notoatmodjo, 2016). The higher the reliability of an instrument, the higher the reliability of the instrument. The reliability coefficient is an important indicator of the quality of the instrument. Interpretations for comparing group levels, coefficients ranging from 0.60 and 0.70 are generally adequate, although coefficients of 0.80 or greater are desirable (Polit \& Beck, 2012).

Based on the results of testing the reliability of research data that all research variables are declared reliable because the Cronbach Alpha value of each variable studied is greater than 0.600 (Cronbach Alpha $>0.600)$. Variable accuracy of food serving $(0,699)$, food performance variable $(0,678)$, food taste variable $(0,608)$, food hygiene variable $(0,799)$, attitudes supporting health workers $(0,610)$, tangible variable $(0,680)$, reliability variable $(0,685)$, responsiveness variable (0.843), assurance variable (0.657), and empathy variable (0.663) (Data attached in the Appendix of the validity and reliability test).

Table 1. Variable Measurement Method

\begin{tabular}{|c|c|c|c|c|}
\hline Variable & $\begin{array}{l}\text { Number of } \\
\text { Items }\end{array}$ & $\begin{array}{c}\text { Value Weight } \\
1 \text { Variable }=1 \text { Variable }\end{array}$ & $\begin{array}{l}\text { Score Weight } \\
\text { Variable }\end{array}$ & $\begin{array}{l}\text { Measure } \\
\text { Scale }\end{array}$ \\
\hline $\begin{array}{l}\text { Dependent Variable } \\
\text { Food hygiene }\end{array}$ & 5 & $\begin{array}{l}\text { Very bad (1) } \\
\text { Bad (2) } \\
\text { Good enough (3) } \\
\text { Good (4) } \\
\text { Very Good (5) }\end{array}$ & $\begin{array}{l}\text { Good }(\geq 19,0) \\
\text { Not good }(<19,0)\end{array}$ & Ordinal \\
\hline Dependent variable & & & & \\
\hline Patient Satisfaction & 25 & $\begin{array}{l}\text { Very bad (1) } \\
\text { Bad (2) } \\
\text { Good enough (3) } \\
\text { Good (4) } \\
\text { Very Good (5) }\end{array}$ & $\begin{array}{l}\text { Good }(\geq 101,0) \\
\text { Not good }(<101,0)\end{array}$ & Ordinal \\
\hline Tangible & 5 & Very bad (1) & Good $(\geq 20,0)$ & Ordinal \\
\hline
\end{tabular}




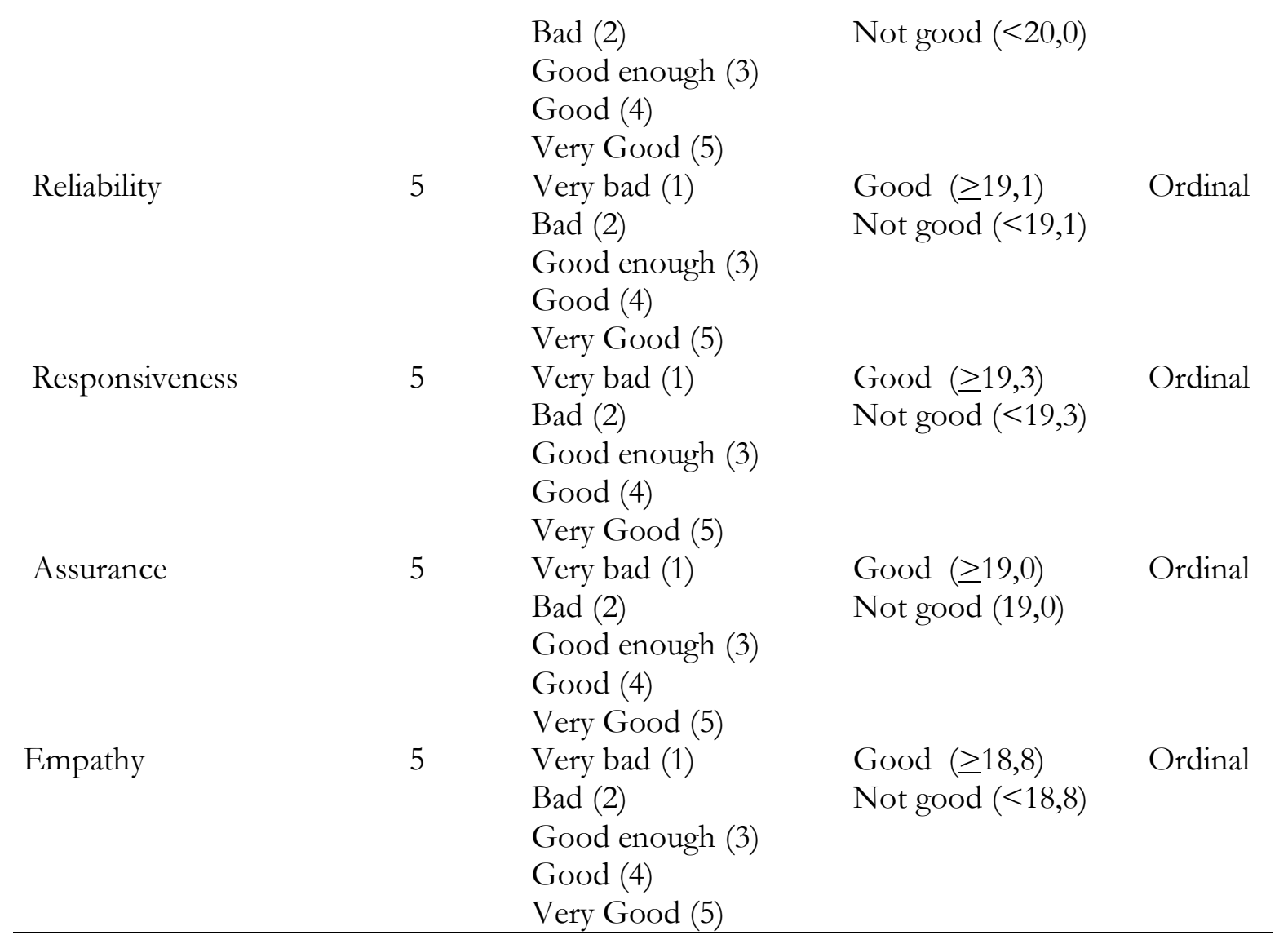
follows:

Aspects of the form of description of the measurement of research variables are as

1. Variable quality of food management, the number of questions for this variable is 25 (twenty five), measured based on the statement of the questionnaire with the highest answer given a score of 5 and the lowest given a score of 1 is calculated using a Likert Scale that is Very Good score of 5, Good score 4, Good enough score 3, Bad score 2, and Very bad score 1.

Highest score $=$ Number of questions $\times$ Highest weight $=25 \times 5=125$

Lowest score $=$ Number of questions $\mathrm{x}$ Lowest weight $=25 \times 1=25$

Normality test results show that the data are normally distributed $(\mathrm{p}=0.210)$ so that the variable categories use the mean value $=95.1$ and are categorized as follows:

a) Good, if the value is $>95.1$ or the range of scores is $96-125$

b) Not Good, if the value $<95.1$ or the range of scores $25-95$

Food hygiene variables, the number of questions for this variable is 5 (five) pieces, measured based on the statement of the questionnaire with the highest answer given a score of 5 and the lowest given a score of 1 is calculated using a Likert Scale namely Very Good (SB) score of 5, Good (B) score 4, Fairly Good (CB) score 3, Not Good (TB) score 2, and Very Not Good (STB) score 1.

Highest score $=$ Number of questions $\mathrm{x}$ Highest weight $=5 \times 5=25$

Lowest score $=$ Number of questions $\mathrm{x}$ Lowest weight $=5 \times 1=5$

Normality test results show that the data are not normally distributed $(\mathrm{p}=0.013)$ so that the variable categories use a median value $=19.0$ and are categorized as follows:

a) Good, if the value is $>19.0$ or the range of score is $19-25$ 
b) Not Good, if a value $<19.0$ or a range of scores $5-18$

Patient satisfaction variable, the number of questions for this variable is 25 (twenty-five) pieces, measured based on the statement of the questionnaire with the highest answer given a score of 5 and the lowest given a score of 1 is calculated using a Likert Scale namely Very Satisfied (SP) score of 5, Satisfied (P) score 4, Moderately Satisfied (CP) score 3, Dissatisfied (TP) score 2, and Very Dissatisfied (STP) score 1.

Highest score $=$ Number of questions $\mathrm{x}$ Highest weight $=25 \times 5=125$

Lowest score $=$ Number of questions $\times$ Lowest weight $=25 \times 1=25$

Normality test results show that the data are not normally distributed $(p=0,000)$ so that the variable categories use a median value $=101.0$ and are categorized as follows:

a) Satisfied, if the value $>101.0$ or the range of scores 101-125

b) Dissatisfied, if the value $<101.0$ or the range of scores $25-100$

2. Variable physical evidence (tangible), the number of questions for this variable is 5 (five) pieces, measured based on the statement of the questionnaire with the highest answer given a score of 5 and the lowest given a score of 1 is calculated using a Likert Scale that is Very Satisfied (SP) score 5, Satisfied (P) score 4, Moderately Satisfied (CP) score 3, Dissatisfied (TP) score 2, and Very Dissatisfied (STP) score 1.

Highest score $=$ Number of questions $\mathrm{x}$ Highest weight $=5 \times 5=25$

Lowest score $=$ Number of questions $\mathrm{x}$ Lowest weight $=5 \times 1=5$

Normality test results show that the data are not normally distributed $(p=0.038)$ so that the variable categories use a median value $=20.0$ and are categorized as follows:

a) Satisfied, if the value is $>20.0$ or the range of scores is $20-25$

b) Not Satisfied, if the value $<20.0$ or the range of scores 5-19

Assurance variable, the number of questions for this variable is 5 (five) pieces, measured based on the statement of the questionnaire with the highest answer given a score of 5 and the lowest given a score of 1 is calculated using a Likert Scale namely Very Satisfied (SP) score of 5, Satisfied ( P) score 4, Moderately Satisfied (CP) score 3, Dissatisfied (TP) score 2, and Very Dissatisfied (STP) score 1.

Highest score $=$ Number of questions $\mathrm{x}$ Highest weight $=5 \times 5=25$

Lowest score $=$ Number of questions $\times$ Lowest weight $=5 \times 1=5$

Normality test results show that the data are normally distributed $(\mathrm{p}=0.052)$ so that the variable categories use the mean value $=19.0$ and are categorized as follows:

a) Satisfied, if the value is $>19.0$ or the range of score is $19-25$

b) Not Satisfied, if the value $<19.0$ or the range of scores $5-18$

Bivariate analysis was carried out to see whether there was a relationship between the independent variable and the dependent variable using the Chi Square test with a significance level $(\alpha)=0.05$ with the calculation of the $2 \times 2$ table. The criteria for acceptance of the results of the chi-square test were: 0.05$)$ then there is a relationship between the independent variable and the dependent variable. Should be accepted if $\mathrm{p}>\alpha(0.05)$ then there is no relationship between the independent variable and the dependent variable.

To see the likelihood of a behavior arising or developing associated with risk factors, a relative risk number is calculated. The calculation of relative risk for the cross sectional study 
design is reflected by the prevalence ratio (PR). Homework is obtained by comparing the prevalence of patients who are satisfied with the prevalence of patients who are dissatisfied.

To read the association relationship, the value of Prevalence Ratio (PR) is determined, as follows: (Sastroasmoro \& Ismael, 2011)

1) If the PR value $>1$ and the range of confidence intervals do not exceed 1 , it means that this variable is a factor that reinforces the satisfaction of inpatients.

2) If the PR value $<1$ and the range of confidence intervals do not exceed 1 , it means that this variable is a protection factor for satisfaction in hospitalized patients.

3) If the PR value $=1$ and the range of confidence intervals do not exceed 1 , it means that this variable has no relationship with inpatient satisfaction.

\section{Discussion}

Based on the respondent's answer to the statement of food hygiene most answered "very good" is statement number 1 namely food served in a closed state as many as 42 people (36.5 percent). The statement that was answered the most "good" was statement number 2 namely rice in white and clean as many as 59 people (51.3 percent). The statement that was mostly answered "quite well" was statement number 5, which was clean and odorless cutlery of 38 people (33.0 percent). The statement that was most answered "not good" was statement number 4, namely side dishes and vegetables in a clean state of 17 people (14.8 percent). While the statement most frequently answered "very poorly" is statement number 5 , which is that drinking glass is always given a lid of 1 person ( 0.9 percent). More can be seen in the following table.

Table 2. Frequency Distribution of Answers for Each Item of Food Hygiene Variables at RSU Royal Prima Medan in 2019

\begin{tabular}{llcccccccccc}
\hline \multirow{2}{*}{ No Statement } & \multicolumn{1}{c}{ Response } \\
\cline { 3 - 11 } & \multicolumn{2}{c}{ SB } & \multicolumn{1}{c}{ B } & CB & \multicolumn{1}{c}{ TB } & \multicolumn{2}{c}{ STB } \\
\cline { 3 - 11 } & $\mathrm{f}$ & $\%$ & $\mathrm{f}$ & $\%$ & $\mathrm{f}$ & $\%$ & $\mathrm{f}$ & $\%$ & $\mathrm{f}$ & $\%$ \\
\hline 1 & Food that is served in a closed state & 42 & 36,5 & 47 & 40,9 & 23 & 20,0 & 3 & 2,6 & 0 & 0 \\
2 & Rice is white and clean & 24 & 20,9 & 59 & 51,3 & 19 & 16,5 & 13 & 11,3 & 0 & 0 \\
3 & Drinking glass is always given a lid & 37 & 32,2 & 43 & 37,4 & 23 & 20,0 & 11 & 9,6 & 1 & 0,9 \\
4 & Side dishes and vegetables are clean & 28 & 24,3 & 39 & 33,9 & 31 & 27,0 & 17 & 14,8 & 0 & 0 \\
5 & Cutlery clean and odorless & 21 & 18,3 & 44 & 38,3 & 38 & 33,0 & 12 & 10,4 & 0 & 0 \\
\hline
\end{tabular}

Furthermore, based on the category of food hygiene in the quality of organizing food at the Royal Prima General Hospital shows that the majority of respondents stated that food hygiene in the good category was 77 people (67.0 percent), which stated not good as many as 38 people (33.0 percent). More can be seen in the following table.

Table 3. Frequency Distribution of Respondents Based on Food Hygiene at Royal Prima General Hospital in 2019

\begin{tabular}{crrcc}
\hline \multirow{2}{*}{ No. } & \multirow{2}{*}{ Food Hygiene } & \multicolumn{2}{c}{ Total } \\
\cline { 3 - 5 } & & 77 & $\%$ \\
\hline 1 & Good & & 38 & 67,0 \\
2 & Not good & & 115 & 33,0 \\
\hline \multicolumn{2}{r}{ Total } & 100,0 \\
\hline
\end{tabular}

Based on the results of the study presented in the cross table of food hygiene with tangible physical evidence shows that of the 77 respondents who stated good food hygiene the 
majority felt satisfied with physical evidence (tangible) as many as 52 people ( 45.2 percent). Of the 38 respondents who stated that food hygiene was not good the majority felt dissatisfied with physical evidence (tangible) of 24 people (20.9 percent).

Statistical test results using the chi-square test obtained $p$-value of $0.003<0.05$ means that there is a significant relationship between food hygiene with tangible evidence at Royal Prima General Hospital in 2019. PR value $=1.833>1$ shows that if food hygiene is good then the patient is satisfied with physical evidence (tangible) 1.8 times compared to those who state that it is not good.

Table 4. Cross Table Relationship of Food Hygiene with Physical Evidence (Tangible) at the Royal Prima Medan General Hospital in 2019

\begin{tabular}{|c|c|c|c|c|c|c|c|c|}
\hline \multirow{3}{*}{ Food Hygiene } & \multicolumn{4}{|c|}{$\begin{array}{c}\text { physical evidence } \\
\text { (Tangible) }\end{array}$} & \multirow{2}{*}{\multicolumn{2}{|c|}{ Total }} & \multirow{3}{*}{$\mathrm{p}$-value } & \multirow[t]{3}{*}{ PR (CI: 95\%) } \\
\hline & \multicolumn{2}{|c|}{ Satisfied } & \multicolumn{2}{|c|}{ Dissatisfied } & & & & \\
\hline & $\mathrm{n}$ & $\%$ & $\mathrm{n}$ & $\%$ & $\mathrm{~N}$ & $\%$ & & \\
\hline Good & 52 & 45,2 & 25 & 21,7 & 77 & 67,0 & & 1,833 \\
\hline Not good & 14 & 12,2 & 24 & 20,9 & 38 & 33,0 & 0,003 & $(1,176-2,858)$ \\
\hline Total & 66 & 57,4 & 49 & 42,6 & 115 & 100,0 & & \\
\hline
\end{tabular}

Based on the research results presented in the cross table of food hygiene with reliability (reliability) showed that of 77 respondents who stated good food hygiene the majority were satisfied with reliability (reliability) as many as 45 people (39.1 percent). Of the 38 respondents who stated that food hygiene was not good the majority felt dissatisfied with reliability (26 people) (22.6 percent).

Statistical test results using the chi-square test obtained p-value of $0.010<0.05$ means that there is a significant relationship between food hygiene and reliability (reliability) at Royal Prima General Hospital in 2019. PR value $=1.851>1$ indicates that if food hygiene is good, the patient is likely to be satisfied with reliability 1.8 times compared to those who state that it is not good.

Table 5. Cross Table Relationship of Food Hygiene with Reliability at the Royal Prima Medan General Hospital in 2019

\begin{tabular}{|c|c|c|c|c|c|c|c|c|}
\hline \multirow{3}{*}{ Food Hygiene } & \multicolumn{4}{|c|}{ Reliability } & \multirow{2}{*}{\multicolumn{2}{|c|}{ Total }} & \multirow{3}{*}{ p-value } & \multirow[t]{3}{*}{ PR (CI: 95\%) } \\
\hline & \multicolumn{2}{|c|}{ Satisfied } & \multicolumn{2}{|c|}{ Dissatisfied } & & & & \\
\hline & $\mathrm{n}$ & $\%$ & $\mathrm{n}$ & $\%$ & $\mathrm{~N}$ & $\%$ & & \\
\hline Good & 45 & 39,1 & 32 & 27,8 & 77 & 67,0 & & 1,851 \\
\hline Not good & 12 & 10,4 & 26 & 22,6 & 38 & 33,0 & 0,010 & $(1,117-3,065)$ \\
\hline Total & 57 & 49,6 & 58 & 50,4 & 115 & 100,0 & & \\
\hline
\end{tabular}

Based on the results of the study presented in the cross table food hygiene with fast response (responsiveness) showed that of 77 respondents who stated good food hygiene the majority were satisfied with fast response (responsiveness) as many as 50 people (43.5 percent). Of 38 respondents who stated that food hygiene was not good the majority felt dissatisfied with responsiveness as many as 31 people (27.0 percent).

Statistical test results using the chi-square test obtained p-value of $0.001<0.05$ means that there is a significant relationship between food hygiene and responsiveness (responsiveness) at Royal Prima General Hospital in 2019. PR value $=3.525>1$ shows that if the cleanliness of food 
is good then the possibility of patients being satisfied with responsiveness (responsiveness) is 3.5 times compared to those who state that it is not good.

Table 6. Cross Table Relationship of Food Hygiene with Quick Response (Responsiveness) at the Royal Prima General Hospital Medan in 2019

\begin{tabular}{|c|c|c|c|c|c|c|c|c|}
\hline \multirow{3}{*}{ Food Hygiene } & \multicolumn{4}{|c|}{ Responsiveness } & \multirow{2}{*}{\multicolumn{2}{|c|}{ Total }} & \multirow{3}{*}{ p-value } & \multirow[t]{3}{*}{ PR (CI: 95\%) } \\
\hline & \multicolumn{2}{|c|}{ Satisfied } & \multicolumn{2}{|c|}{ Dissatisfied } & & & & \\
\hline & $\mathrm{n}$ & $\%$ & $\mathrm{n}$ & $\%$ & $\mathrm{~N}$ & $\%$ & & \\
\hline Good & 45 & 39,1 & 32 & 27,8 & 77 & 67,0 & & 1,851 \\
\hline Not good & 12 & 10,4 & 26 & 22,6 & 38 & 33,0 & 0,010 & $(1,117-3,065)$ \\
\hline Total & 57 & 49,6 & 58 & 50,4 & 115 & 100,0 & & \\
\hline
\end{tabular}

Based on the results of research presented in the cross table of food hygiene with guarantees (assurance) showed that of 77 respondents who stated good food hygiene the majority were satisfied with the guarantee (assurance) as many as 56 people (48.7 percent). Of the 38 respondents who stated that food hygiene was not good the majority felt dissatisfied with the guarantee as many as 25 people (21.7 percent).

Statistical test results using the chi-square test obtained p-value of $0.001<0.05$ means that there is a significant relationship between food hygiene and assurance at Royal Prima General Hospital in 2019. PR value $=2.126>1$ indicates that if food hygiene is good, the patient is likely to be satisfied with a guarantee 2.1 times compared to those who state that it is not good.

Table 7. Cross Table Relationship of Food Hygiene with Assurance at the Royal Prima General Hospital, Medan in 2019

\begin{tabular}{ccccccccc}
\hline & \multicolumn{4}{c}{ Assurance } & \multicolumn{2}{c}{ Total } & \multirow{2}{*}{ PR (CI: 95\%) } \\
\cline { 2 - 6 } Food Hygiene & \multicolumn{3}{c}{ Satisfied } & \multicolumn{2}{c}{ Dissatisfied } & & & \\
\cline { 2 - 7 } & $\mathrm{n}$ & $\%$ & $\mathrm{n}$ & $\%$ & $\mathrm{~N}$ & $\%$ & & \\
\hline Good & 56 & 48,7 & 21 & 18,3 & 77 & 67,0 & & 2,126 \\
Not good & 13 & 11,3 & 25 & 21,7 & 38 & 33,0 & 0,001 & $(1,340-3,373)$ \\
\hline Total & 69 & 60,0 & 46 & 40,0 & 115 & 100,0 & & \\
\hline
\end{tabular}

Based on the results of the study presented in the cross table food hygiene with satisfaction shows that of the 77 respondents who stated good food hygiene the majority were satisfied as many as 52 people (45.2 percent). Of 38 respondents who stated that food hygiene was not good the majority felt dissatisfied as many as 29 people ( 25.2 percent).

Statistical test results using the chi-square test obtained p-value of $0.001<0.05$ means that there is a significant relationship between food hygiene and inpatient satisfaction at Royal Prima General Hospital in 2019. PR value $=2.851>1$ indicates that if food hygiene is good, the patient is likely to be 2.8 times more satisfied than those who declare not good.

Table 8. Cross Table Relationship of Food Hygiene with Patient Satisfaction at the Royal Prima General Hospital Medan in 2019

\begin{tabular}{lccccccccc}
\hline \multirow{3}{*}{ Food Hygiene } & \multicolumn{4}{c}{ Patient Satisfaction } & \multicolumn{3}{c}{ Total } & \multirow{2}{*}{ PR (CI: 95\%) } \\
\cline { 2 - 6 } & \multicolumn{2}{c}{ Satisfied } & \multicolumn{2}{c}{ Dissatisfied } & & & & \\
\cline { 2 - 7 } & $\mathrm{n}$ & $\%$ & $\mathrm{n}$ & $\%$ & $\mathrm{~N}$ & $\%$ & & \\
\hline Good & 52 & 45,2 & 25 & 21,7 & 77 & 67,0 & 0,001 & 2,851 \\
\hline
\end{tabular}




\begin{tabular}{|c|c|c|c|c|c|c|c|c|}
\hline \multirow{3}{*}{ Food Hygiene } & \multicolumn{4}{|c|}{ Patient Satisfaction } & \multirow{2}{*}{\multicolumn{2}{|c|}{ Total }} & \multirow{3}{*}{ p-value } & \multirow[t]{3}{*}{ PR (CI: 95\%) } \\
\hline & \multicolumn{2}{|c|}{ Satisfied } & \multicolumn{2}{|c|}{ Dissatisfied } & & & & \\
\hline & $\mathrm{n}$ & $\%$ & $\mathrm{n}$ & $\%$ & $\mathrm{~N}$ & $\%$ & & \\
\hline Not good & 9 & 7,8 & 29 & 25,2 & 38 & 33,0 & & $(1,578-5,151)$ \\
\hline Total & 61 & 53,0 & 54 & 47,0 & 115 & 100,0 & & \\
\hline
\end{tabular}

Based on the results of the study showed that there is a significant relationship between food hygiene and inpatient satisfaction at the Royal Prima General Hospital, Medan. The majority of respondents who stated that food cleanliness was satisfied were satisfied. The majority of respondents who stated that food hygiene was not good were dissatisfied. Cleanliness is considered not only food but also the equipment used when the food is served. Patient dissatisfaction with food hygiene makes the patient less appetite, and this is evident from the remaining food on the plate is still a lot, patients only spend a quarter or half the portion provided.

Based on the results of this study prove that food hygiene is significantly associated with inpatient satisfaction at the Royal Prima General Hospital Medan. Respondents who stated that the food displayed was clean tended to be satisfied whereas respondents who stated that the food displayed was less clean tended to be dissatisfied. Patient satisfaction with food hygiene is caused by food served in a condition covered in rice or porridge with a clean white appearance, as well as vegetables and side dishes maintained clean. Besides food, cutlery used for eating also looks clean like plates and spoons. Cleanliness is important in food service in hospitals because clean food and equipment will ensure the health of inpatients who consume it. Food and eating utensils that are clean will make hospitalized patients at the Royal Prima General Hospital Medan become appetite and have an impact on the amount of food consumed by patients so that it will make the patient's health better for recovery.

Some respondents felt that it was not good with regard to food hygiene at the Royal Prima Medan General Hospital according to respondents, namely food that was served was sometimes not covered while covering food with plastic in addition to maintaining food warmth so that food was always clean not contaminated by dust, the smell of the house sick, or avoid insects such as flies perch on food. Likewise, there were some respondents who said that the rice / porridge served was not clean enough. The condition of the cutlery is not clean though it does not smell. Things that were considered not good by some respondents were side dishes and vegetables that were not clean enough. Things that are considered not very good such as drinking glasses are not always given a lid, because drinking glasses that are not closed can cause drinking smells of hospital odors and this can reduce respondents' appetite.

\section{Conclusion}

Based on the results of research that has been done and presented in the discussion in the previous chapter, it can be concluded that food hygiene is related to satisfaction of inpatients. If the food hygiene is good, the patient is probably 2.8 times more satisfied than those who claim to be bad.

\section{References}

Aditama, T. Y. (2016). Manajemen Administrasi Rumah Sakit (Cetakan 4). Jakarta: Universitas Indonesia Press.

Agustina, F. (2016). Hubungan Antara Daya Terima Makanan Dengan Tingkat Kepuasan 
Pelayanan Gizi Pasien Hipertensi Rawat Inap Di RSUP Dr Soeradji Tirtonegoro Klaten. Program Studi Ilmu Gizi Fakultas Ilmu Kesehatan Universitas Muhammadiyah Surakarta.

Azwar, A. (2015). Menjaga Mutu Pelayanan Kesehatan Aplikasi Prinsip Lingkaran Pemecahan Masalah (Cetakan 3). Jakarta: Pustaka Sinar Harapan.

Bustami. (2016). Penjaminan Mutu Pelayanan Kesehatan \& Akseptabilitasnya (Cetakan 2). Jakarta: Erlangga.

Cornelia. (2014). Penuntun Konseling Gizi (Cetakan 1). Jakarta: Abadi Pustaka.

Ernalia, Y. (2014). Faktor-Faktor Yang Berhubungan Dengan Kepuasan Pasien Di Ruang Penyakit Dalam Dan Ruang Bersalin Terhadap Pelayanan Makanan Pasien Di RSUD Mandau Duri Tahun 2014. LPPM Tuankutambusai.

Fernika, O. S. (2017). Hubungan Ketepatan Waktu Penyajian Makanan, Penampilan Makanan dan Rasa Makanan dengan Kepuasan Pasien DM Rawat Inap Kelas II dan III di RS Islam Siti Khadijah Palembang Tahun 2017. Program Studi D-III Gizi Politeknik Kesehatan Palembang.

Herlambang, S. (2016). Manajemen Pelayanan Kesehatan Rumah Sakit (Cetakan 1). Yogyakarta: Gosyen Publishing.

Kemenkes RI. (2008). Keputusan Menteri Kesehatan Republik Indonesia Nomor : 129/Menkes/SK/II/2008 tentang Standar Pelayanan Minimal Rumah Sakit. Jakarta: Kementerian Kesehatan Republik Indonesia.

Kemenkes RI. (2011). Peraturan Menteri Kesehatan Republik Indonesia Nomor 1096/Menkes/Per/ VI/2011 Tentang Higiene Sanitasi Jasaboga golongan A, B, dan C. Jakarta: Kementerian Kesehatan Republik Indonesia.

Kemenkes RI. (2012). Pedoman Pelayanan Gizi Rumah Sakit. Jakarta: Kementerian Kesehatan Republik Indonesia.

Kemenkes RI. (2013). Peraturan Menteri Kesehatan Republik Indonesia Nomor 78 Tahun 2013 Tentang Pedoman Pelayanan Gizi Rumah Sakit. Jakarta: Kementerian Kesehatan Republik Indonesia.

Kemenkes RI. (2014). Gizi Seimbang Menuju Hidup Sehat. Jakarta: Kementerian Kesehatan Republik Indonesia.

Kotler, P. (2013). Manajemen Pemasaran (Cetakan 8). Jakarta: Erlangga.

Lovelock, H. C., \& Wright, K. L. (2012). Manajemen Pemasaran Jasa (Cetakan 2; A. Widyantoro, Ed.). Jakarta: Indeks.

Mustafa, E. (2012). Tingkat Kepuasan Pasien Rawat Inap Terhadap Pelayanan Makanan Di Rumah Sakit Umum (RSUD) Mamuju Provinsi Sulawesi Barat. Media Gizi Masyarakat Indonesia, 2(1), 27-32.

Nafies, D. A. A. (2016). Hubungan Cita Rasa Makanan Dan Konsumsi Makanan Dari Luar Rumah Sakit Dengan Sisa Makanan Biasa Pada Pasien Di Rumah Sakit Orthopedi Prof. Dr. R. Soeharso Surakarta. Fakultas Ilmu Kesehatan Universitas Muhammadiyah Surakarta.

Pemerintah RI. (2009). Undang-undang Republik Indonesia Nomor 44 tahun 2009 tentang Rumah Sakit. Jakarta: Lembaran Negara Republik Indonesia Tahun 2009 Nomor 153.

Trisnawati, P. I. (2018). Manajemen Penyelenggaraan Makanan Pasien Di Rumah Sakit Pusat Angkatan Udara Dr. S. Hardjolukito Yogyakarta. Program Studi Pendidikan Teknik Boga Fakultas Teknik Universitas Negeri Yogyakarta.

Wigiantoro, E., Irene, M., \& Purnami, C. T. (2013). Hubungan Mutu Pelayanan Petugas Gizi dengan Kepuasan Pasien dalam Pelayanan Gizi pada Rawat Inap di RSUD Kajen Kabupaten Pekalongan Correlation between Quality of Nutritional Workers Services and Patient' s Pekalongan District. Manajemen Kesehatan Indonesia, 01(03), 178-186.

Yuwono, T., \& Silvita, I. S. (2015). Kamus Lengkap Bahasa Indonesia (Cetakan 2). Surabaya: Arkola. 